\title{
American Missionaries in Revolutionary Russia
}

\section{Dr. Lyubov Ginzburg}

\section{Americans in the city of clerks and foreigners}

As an American Studies scholar and native of St. Petersburg, Russia, Leningrad at my birth, I always wondered why so little attention had been devoted to the American presence in the "city of clerks and foreigners." I thus dedicated myself to write yet another chapter in the international history of Russia's northern capital, which would reveal an extensive yet unjustly overlooked narrative about a colony of American nationals residing in the city, where they were engaged in political, business, cultural, spiritual, and charitable pursuits in the decades surrounding the turn of 20th century, an era of widespread warfare and social upheaval.

In the course of their sojourns to Russia, many American expatriates gained a deep attachment to their host country and respect for its inhabitants, developing an interest in its history, politics, social order, and rich cultural traditions. Often their engagements with Russia took place beyond the purview of governmental policymakers, near the dawn of an age of public diplomacy that today is becoming a sought-after mode of international communications. Finding themselves in the midst of dramatic events that changed the course of world history, Americans represented a vanguard of good-willed citizens directing their efforts toward a decisive manifestation of benevolence and determination that left a pronounced and long-lasting impact on the legacy of Russian-American dialogue. As true patriots, they inserted themselves and their ideals upon St. Petersburg's social milieu by promoting American values and interests. At the same time, through their direct involvement in the life of the city and close relations with natives, Americans often liberated themselves from the most notorious misconceptions about Russia, finding significant implications for new views of themselves.

Many pioneers of public diplomacy were passionately devoted to sharing what they saw and experienced. Being attentive and articulate commentators who experienced life in the Russian capital first hand, many left memoirs, diaries and articles, becoming chroniclers of the turbulent developments of the wartime years and the revolution. Comprising subjective sentiments and observations, these accounts provide an essential link between personal and public discourses in interpreting and understanding history. They also reveal their creators' intentions to foster an appreciation for Russia's ancient culture in the West, while dispelling 
widely-spread and firmly established notions of the country as a backward and hostile place.

This essay is dedicated to the history of the American religious establishment in Russia, the role of American missionaries in large-scale relief operations, and the promotion of "good feeling [toward America and Americans] among Russians." After all, it was their charity and efforts to help Russian communities that prompted gratitude toward the American nation and people, diminishing the misunderstanding and mistrust among Russians (Perovsky, 1920). Thanks to the considerable growth of its congregations, support for orphanages and lazarets, provision of humanitarian aid, and theological training of ministers, the American Methodist Episcopal Church gained a favorable reputation and secured a prominent place among multiple denominations of a culturally and religiously-diverse city. American missionaries contributed not only to foreign communities, whose social and spiritual needs they came to meet, but also enhanced the lives of natives of St. Petersburg / Petrograd, who greatly appreciated their efforts. ${ }^{1}$ Work in Russia also benefitted Americans themselves. Although their missionary campaigns often overlapped, in the words of David S. Foglesong, with "political crusades and economic drives to remake Russia" $(1997,361)$, their experience in that country also helped Americans reflect critically upon assumptions, implications and inferences about their own homeland, its mores and values.

While examining materials in major Russian and American archival depositories such as the Library of Congress, the National Library of Russia, and the Russian State Historical Archive, among others, I also utilized many less known sanctuaries of preserved evidence of the past, indispensable in the challenging process of untangling the knot of fragmentary episodes, assembling them into a meaningful and cohesive narrative about the lives of previous generations. One of those, the United Methodist Church Archives, in Madison, New Jersey, is the primary depository for reconstructing the history of American missionaries, in particular the United Methodist Church in pre- and revolutionary Russia.

\section{An American church in the Russian capital}

As with many foreign communities in the multinational metropolis, it was the church that became a center of social and religious life for American expatriates, as well as for natives comprising various nationalities and ethnic groups. Missionaries' enthusiasm "extended well beyond denominational mission boarders," with "over one hundred and eighty million souls in Russia [... ] eagerly looking toward

1 Russians both at home and abroad praised the efforts of various American non-governmental organizations. After the Bolshevik Revolution, many of those Russians who fled abroad relied on American relief activities and hoped that with their help a devastated Russia could be brought back to normal life. Thus for example in a letter addressed to Isabel Hapgood, who herself was involved in various enterprises helping émigrés, émigré groups, and those left behind in Russia, Count Perovsky, who was a head of a Russian colony in Norway cited the impressions of his son fighting with Yudenich and bringing his first hand impressions from Ukraine: "the only 'allied' organization there he is able to speak about with praise is the American Red Cross society." (Perovsky, 1920). 
America for political, commercial and religious help" (cited in Foglesong, 1997, 360). There was a dramatic increase in missionary activity following the tsarist government's 1903 broadening of religious freedom, and the April, 1905 edict on religious toleration (Foglesong, 1997, 356). The congregations and American parishioners in the city had a rich spiritual history and a reputation for religious tolerance. ${ }^{2}$ Foglesong describes close connections between their mission, the involvement of the American colony, and unfolding relief activities. Among religious and charitable organizations with operations in Russia at the turn of the twentieth century were the YMCA, founded by American philanthropist James Stokes and known to Russians as Mayak, ${ }^{3}$ the American Red Cross Society, the Salvation Army, and the American Methodist Episcopal Church. Besides the Anglo-American Church, founded by British Protestants in 1753 near the Admiralty, frequented by John Quincy Adams and members of his household, and the Congregational Anglo-American Church that occasionally served as a gathering place for the Russian chapter of the British corps of the Salvation Army, Americans also flocked to the Methodist-Episcopal Church, known as the American Chapel, or Church of Christ Our Savior. It was situated on Vasilievski Island in a wooden building that has not survived (Bertash, 155). ${ }^{4}$ The church was solemnly founded in December 1914, and on 1 March that year 125 people attended the dedication ceremony (Christian Advocate, no. 73 (January 1915), 11). By that point there were more than 130 parishioners from at least nine nationalities attending services in a variety of languages (Teryukova, 144). ${ }^{5}$

2 Foglesong describes the new religious repression following the outbreak of the Great War, but at the same time, referring to Pastor George Simons' correspondence, he concludes that missionaries in Petrograd continued to enjoy 'a certain amount of liberty' (Foglesong, 1997, 359).

3 In 2013 Matthew Lee Miller published The American YMCA and Russian Culture, which is the most comprehensive history of the YMCA in Russia and its relief work, including assistance to the prisoners of war, and its impact on Russian and Soviet life.

4 The building was demolished in 1931. John Dunstan, the author of an article "George A. Simons and the Khristianski Pobornik: A neglected Source on St. Petersburg Methodism," wrote that the purchase of the property was possible thanks to an American benefactress, Mrs. Fanny Nast Gamble (35).

5 It is mentioned in an article that the services were offered in Finnish, German, English, Swedish, Russian, and Estonian (Teryukova, 144). The history of earlier American missionaries and those, who, similar to Methodist F.W. Flocken, preached as early as in 1860s in the Danube delta, or Seventh-day Adventist Ludwig Richard Conradi, who proselytized in Southern Russia between 1886 and 1905, is described in the works of David S. Foglesong. See, for example his book The American Mission and the 'Evil Empire'. (2007). Cambridge: Cambridge University Press, or his earlier article "Redeeming Russia? American Missionaries and Tsarist Russia, 1886-1917," Religion, State and Society, vol. 25, No. 4 (1997): 356-359. Foglesong states that "Russia's enormous territory and population were crucial inducements" (Foglesong, 1997, 355). Among other sources on early Methodism in Russia, see Steven T. Kimbrough, Jr., ed. 1995. Methodism in Russia and the Baltic States: History and Renewal. Nashville: Abingdon Press; Teryukova, Ekaterina Aleksandrovna. (2009). Angloiazychnye protestantskie obshchiny Peterburga nachala XX veka: verouchenie i sotsial'naia deiatel'nost' (English speaking Protestant communities of 


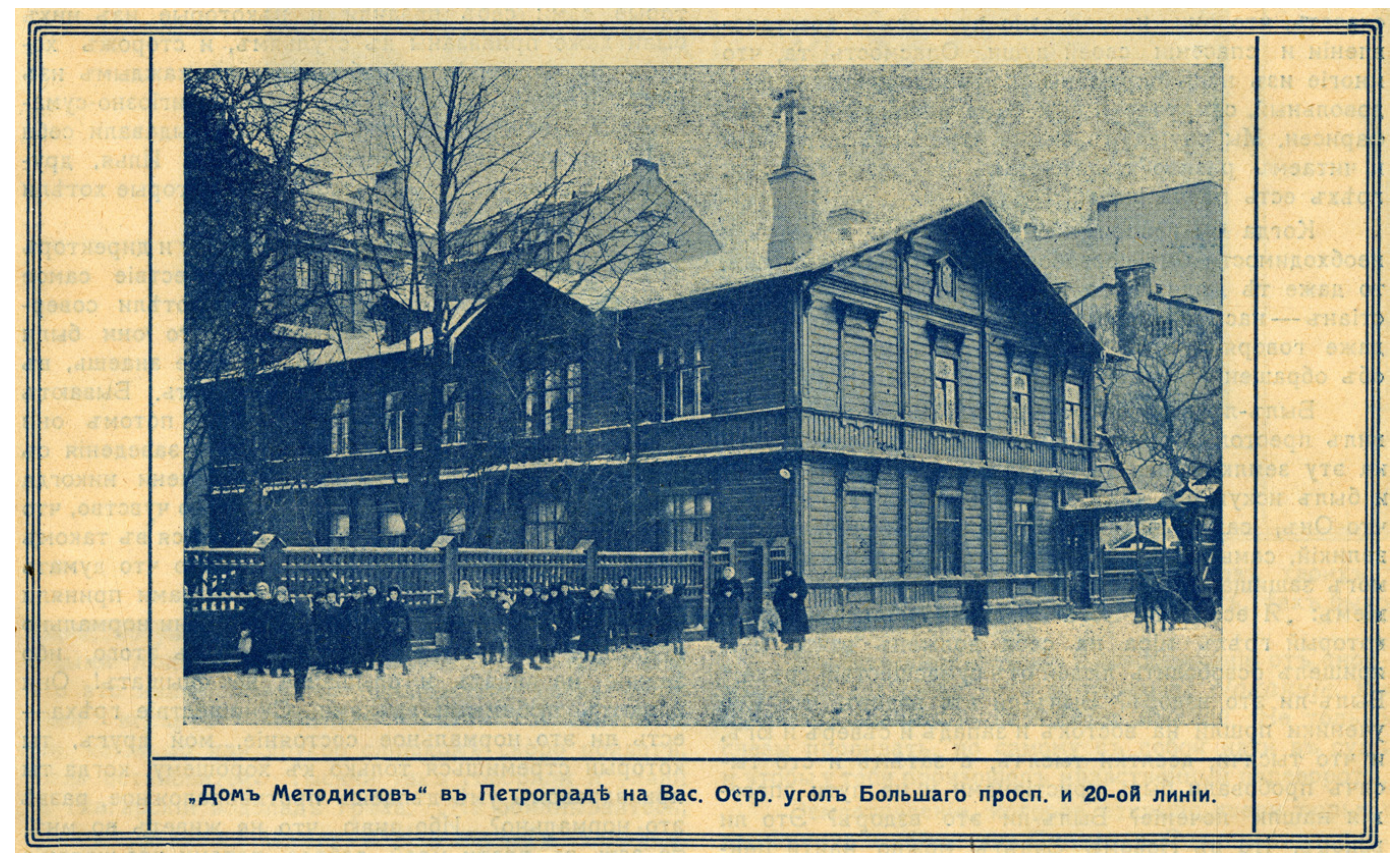

The House of Methodists, Petrograd, 1915. Christian Advocate, no. 75 (March 1915)

As Donald Carl Malone mentioned in his article on the history of Methodism in Russia, the "ministry [...] was an unqualified success. [...] followers increased rapidly, and their work extended into social concerns and publishing interests" (240). The mission quickly evolved into the cultural and social center of the American colony in St Petersburg, and a favorite of neighborhood residents, who would drop by either for Sunday $\operatorname{school}^{6}$ or for free English classes open to all. John Dunstan, the author of the most comprehensive research on the St. Petersburg / Petrograd Methodist publication Khristianski Pobornik (Christian Advocate), mentioned the Finnish-speaking residents, as well as the Swedish community, and tied the history of Methodism in the Russian capital to the considerable social diversity of the city's population - especially on the island where the church was situated (23). ${ }^{7}$

\section{American pastor at the foundation of public diplomacy}

Its founder was George Albert Simons (1874-1952), an American Methodist pastor from New York, who became superintendent of the Finland and Petersburg

Petersburg in the beginning of the 20th cent.: religious doctrine and social activity). SanktPeterburg: IPTS SPGUTD.

6 The Sunday School was run by Vladimir Datt with a board of eight men and seven women teachers. Dunstan referred to Methodists' publication Christian Advocate and wrote that American pastor George Simons himself led classes and that the Sunday School had raised 175 roubles to support a school in China and 3,200 roubles for "self-support, benevolent and missionary purposes" (32).

7 Dunstan analyzed the content of the publication of Petersburg / Petrograd Methodists Christian Advocate and concluded that by 1910 the Conference of the Finland and St. Petersburg Mission claimed a congregation of 500, of nine different nationalities (32). 
Mission. ${ }^{8}$ Simons eventful Russian experience is well-documented in his extensive correspondence, reports sent back to the United States, publications, press clippings from his time in Russia, and photographically, in images, some of which have not been previously published. Most of these materials are in the Missionary Files Series of the United Methodist Church Archives in New Jersey.

Simons' friend and biographer, the editor of the Riga Times, Leslie A. Marshall, believed that "there must be such thing as Fate." When Bishop William Burt, the director of Methodist missions in Europe, secured missionary funds for Russia and encouraged George Simons "to take charge of that formerly languishing territory" (Foglesong, 1997, 356) in 1907, Simons was not very enthusiastic about his new assignment, as he was "deeply prejudiced against the Russian character, language, and customs, and aware of the danger lurking in a land that might flare up in a revolution any hour" (Marshall, 20,43). Nonetheless, Simons spent twenty years pioneering the Methodist Episcopal Church in Russia and the Baltic States, serving as the superintendent of the Finland and Petrograd Mission between 1907 and 1911, and remaining a pastor of the American Methodist Episcopal Church in Petrograd until October 1918. After eight years in the country, Simons himself recollected that in the course of his tenure in "dear old Russia [he] has had ample opportunity to study that great Slavic nation at first hand." The first Russian phrase that the pastor learned was the often-quoted phrase: "shirokaya russkaya natura - the broad Russian nature'-an expression, which pithily characterized the wonderfully generous soul of the [Russian] people" (Christian Advocate, № 85, (January 1916), 13). After the February Revolution, the American pastor perceived the challenges that his mission had to endure as an unprecedented opportunity he faced "for the gospel's sake" (Malone, 240). Sharpe Wilson, a member of the British committee for carrying on the affairs of the English-speaking community, who happened to conduct a service at the Congregational Church in St. Petersburg and at the Church of England during the rule of Bolsheviks, described his friend and "brother-in-arms" George A. Simons as a man "gifted with a fine command of language in which he express his thoughts in prose as well as in verse" (cited in Marshall, 12). Simons remained in Russia, among a few other missionaries, continuing his duties in spite of enormous hardship. Along with the

8 Although Dunstan named Bengt August Carlson (1833-1920), an American of Swedish birth, to be the first ordained Methodist missionary to work in St. Petersburg, the permanent mission in the Russian capital was "easier contemplated than done" (24). In 1904 there were just 20 members. Only in 1906, with the "Edict of Toleration" released in April 1905 the situation began to improve and in March 1907 a Finnish- and Russianspeaking pastor, Hjalmar F. Salmi, born in St. Petersburg and educated at a Methodist school in Finland, was joined by George Albert Simons. The latter found a mission which consisted of "ten aged women and a feeble man, not one of whom belong to the church" (cited in Dunstan, 25-26, Simons, Albert George. (1910). "Report of the Superintendent". In Annual Report of the Board of Foreign Mission of the Methodist Episcopal Church for the Year 1910, 478. New York, The Board of Foreign Mission, 1911). Dunstan provided extensive information about Simons, including his training at Baldwin-Wallace College, Berea, Ohio, New York University, and Drew Theological Seminary, as well as about his assignments as ordained pastor (Dunstan, 26). 
YMCA, which persisted with its work throughout 1918, "proceeding as usual, with fair attendance" (Lowrie, 1918), the American Methodist Episcopal Church was the last to close its operations. When Americans were forced to leave the capital, in the aftermath of the Bolshevik uprising, Simons was one of the last to depart. Seeking an opportunity to remain in Russia, he wrote Grigorii Zinoviev on 14 September 1918:

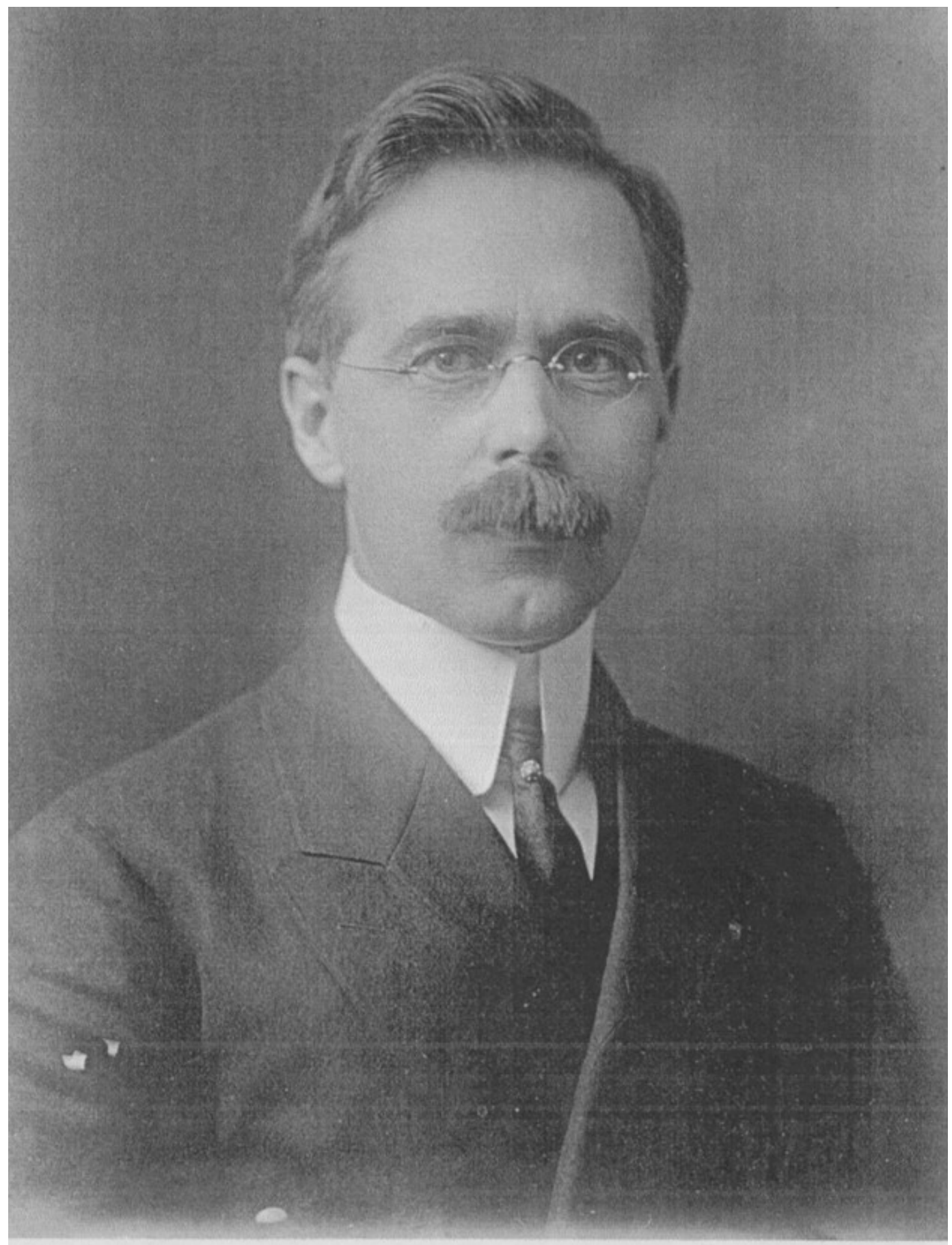

George Albert Simons (1874-1952). Simons File 1185-1-3:19. Missionary Files Series, United Methodist Church Archives, Madison, New Jersey. Courtesy of the United Methodist Commission on Archives and History. 
...my sympathies are naturally with the laboring classes, among who our church in America and in other parts of the world, I am proud to say, has always been known as a staunch champion of the workmen. ...you will clearly see how very necessary it is that I should remain here... I wish to assure you and your colleagues that we are always willing to cooperate in every possible way to help our dear Russian friends. (Simons File, 1918) ${ }^{9}$

Besides the workmen who paid visits to the House of Methodists to hear Simons' passionate and inspiring sermons, or attend an English class, the pastor was acquainted with the president of the Academy of Science, Grand Duke Konstantin Romanov, Pyotr Stolypin, and befriended a deputy of St. Petersburg's Duma, prominent businessman San-Galli. The American pastor was invited to preach at an English club, an American Luncheon club, and the Anglo-American Church. He became truly infatuated with the city and its people, considering it his duty to educate Americans about Russian politics and culture utilizing a modest publishing enterprise. The first quarterly publication was entitled Methodism in Russia and published in Rome in English. It was followed by the Methodist periodical Christian Advocate, ${ }^{10}$ with the first issue released in 1909.

\section{Christian Advocate - a newsletter of the American colony}

Established initially for acquainting its readers with doctrine, hymns and sermons by famous Methodists, the publication later evolved into a bilingual newsletter, reporting on social news and unfolding events, such as the American entrance into WWI, or Tsar Nicholas II's Abdication Proclamation. During the war years, it was an especially challenging enterprise. Simons explained that publishing such a paper was "almost a nerve-breaking undertaking," with "practically all experienced printers and compositors having been called into the army" (Christian Advocate, № 86, (February 1916), 40(24)). Such a "modest bilingual monthly" as Christian Advocate played a unique role in the city. While published in Petrograd, it also sought to serve Americans in Moscow and other Russian centers. Since 1915 it had been dedicated as a monthly Russian-English religious periodical, an official publication of the American Methodist Episcopal Church and the American Colony in Petrograd. It reported on events taking place within the American community and in diplomatic circles, such as appointments, resig-

9 Only a few months after writing the aforementioned letter, in February 1919, Simons would testify before the Senate Overman Committee, describing the Bolsheviks as "demons", and explaining his own position as one of a Christian Socialist. The Pastor finally returned to New York in October 1918. United States Congressional Committee on the Judiciary, 1919. Bolshevik Propaganda. Hearings before a Subcommittee of the Committee on the Judiciary United States Senate, Sixty-fifth Congress, Third Session and Thereafter, Pursuant to S. Res.439 and 469. February 11, 1919, to March 10, 1919. Washington, 121.

${ }^{10}$ The author undertook a thorough research of an almost complete set of the publication, which has been preserved at the National Library of Russia, spanning the years 1909-1917. 
nations, obituaries, and updates on social gatherings in the capital, etc. Thus, from the January 1916 issue, under the column "Items of Interest," American residents learned about Captain David Hough's late return from the United States and his failure to return to Russia soon enough to spend Christmas with his family, due to "the heavy holiday travel and extreme cold which froze up the piping on the locomotives" (Christian Advocate, № 86, (February 1916), 40(24)). They also could read about an exhibition of a fashionable English painter, whose pictures "were noted for their remarkable color-tones," displayed at the house of Mr. and Mrs. McAllister Smith, of Guarantee Trust, that promised to be "a striking illustration" of his art. It was a fund-raiser which opened with a program featuring "Mrs. W.C. Whiffen and Mrs. Barnes, performing several classic selections on the piano, with Mary Knechen singing Russian songs, and Mrs. McAllister Smith, wife of Mr. L. McAllister Smith of the Guarantee Trust, rendering Elizabeth Barret Browning's poem entitled 'Mother and Poet,' with genuinely dramatic expression" (Christian Advocate, № 85, (January 1916)). The event raised 943 roubles for the American Refuge. ${ }^{11}$ The same issue announced David Bell McGowan's transfer to Moscow following his appointment as a vice-consul there. The journal reported: "As a newspaper man of twenty-five years' experience and having been in Russia and other parts of Europe for some years, Mr. McGowan will prove himself a most official man in the consular service. His many friends in Petrograd join in heartiest congratulations, regretting however that he is leaving them so soon again" (Christian Advocate, № 85, (January 1916), 40 (24)). Readership included subscribers in Canada, France, Switzerland and America. The monthly also carried news about Russian cultural matters. In 1915, Simons published a set of poems by the Great Duke Konstantin Konstantinovich. ${ }^{12}$

It is worth noting the changing attitudes regarding the political situation in Russia, especially in the course of the turmoil of revolutionary events. If in 1911 the journal was honoring the Romanov dynasty, when the first Russian revolution took place in February 1917, the periodical released a "truly people's anthem," "Brotherhood, Love, and Freedom," composed by the pastor himself (Teryukova, 145). ${ }^{13}$ The piece was dedicated to "the great resurrected free Russia." The royalties were donated to pay tribute to the victims of the revolution (Teryukova, 145). Also in the April-May issue was an account of a mass meeting in the Duma (State Council), upon the occasion of America's entry into the war, at which pastor Simons spoke, and a poem by Aksakov entitled "Free Speech," which had been banned for 70 years (Dunstan, 39). In the English section, Simons published an

${ }^{11}$ The same issue announced about the Refuge opening on the 1 January 1916 stressing "a large number of Americans and Russian advocates being present," and acknowledging that it was "highly gratifying to know this worthy cause has already received sympathetic and generous support of American and Russian friends in Petrograd (Christian Advocate, № 85, (January 1916)).

12 The author has not been able to locate this 1915 bilingual edition of selected poems composed by Konstantin Romanov and translated by Franklin A. Gaylord, the "poet laureate' of the American Colony.

${ }^{13}$ It is not known who is the author of the words, but it is believed that Pastor composed the music himself. 
article on 'Russia's Resurrection,' in which he declared that the February revolution was "the most thrilling thing" he witnessed in his ten-year sojourn in Russia and defined the political metamorphosis as a transformation "from the gloomy tomb of despotic tyranny and medieval terrorism into the joyous light and life of freedom and democracy" (Christian Advocate, no. 100-101 (April-May 1917), 37, 42-45). As the chief editor, Simon established similar editions in Latvian, Estonian and Lithuanian, issued hymnbooks, Wesley's sermons and catechisms in all these languages, and served as editor of the Baltic and Slavic Bulletin in English (Marshall, 25-26). As one appreciative reader mentioned in his letter to the editor, there was "no other paper just like it!" The Christian Advocate also served as a bibliography of English language sources on Russia.

\section{Other publishing initiatives}

Occasionally the publishing house released a limited number of editions which might be considered a bibliographical rarity and early effort to challenge the political discourse dominating area studies and international relations with elements of social and cultural history. In the course of the war, the church and its pastor became part of the American committee that established a hospital for wounded soldiers. Pastor Simons worked closely with the American Red Cross, American embassy and other members of the American colony. Methodists' publications recounted the devotion to serving the underprivileged and the American response to the needs of victims of the ongoing conflict, alleviating the sufferings of refugees, prisoners of war, and wounded Russian soldiers. A selection of Letters from Russian Soldiers addressed to American personnel at the American City Hospital is an example, translated by a Ms. Potter, a sister-in-law of a long-time member of the American colony Frederick Corse, the head of the Russian branch of New York Life. The translator attempted to preserve the letters' somewhat "archaic character," derived from Russian peasants' familiarity with the Bible and traditional folk tales. Soldiers and their families expressed gratitude for the care and treatment received in the midst of squalor and misery, revealing "simple, poetic style and the genuine depth of feelings." These living documents of "inestimable historic value," preserve a record of the manifestation of goodwill, and also emphasize American appreciation for the privilege of working with and learning from those "big-hearted" fellows who were "so easy to please and so truly grateful for what was done for them" (City Hospital of the American Colony, 3). ${ }^{14}$

Equally important, at least for the era, was a publication disseminated at the World's Seventh Sunday School Convention in Zurich in 1913. The brochure is entitled "And the Rest of Europe: The Response for Russia in the Roll Call of Nations." Simons recalled that it was prompted by a curious episode during convention registration. Passing the Scandinavian booth, the pastor saw a sign "the rest of Europe." Intending to elaborate upon such an 'indefinite definition' of that

${ }^{14}$ New York Times also acknowledged the release of the pamphlet ("Russian Soldiers Are Grateful to Americans: Letters to Sisters of American Hospital Are Examples of a Literary Style Which Follows the Bible and Old Fairy Tales." New York Times, June 25, 1916, SM12). 


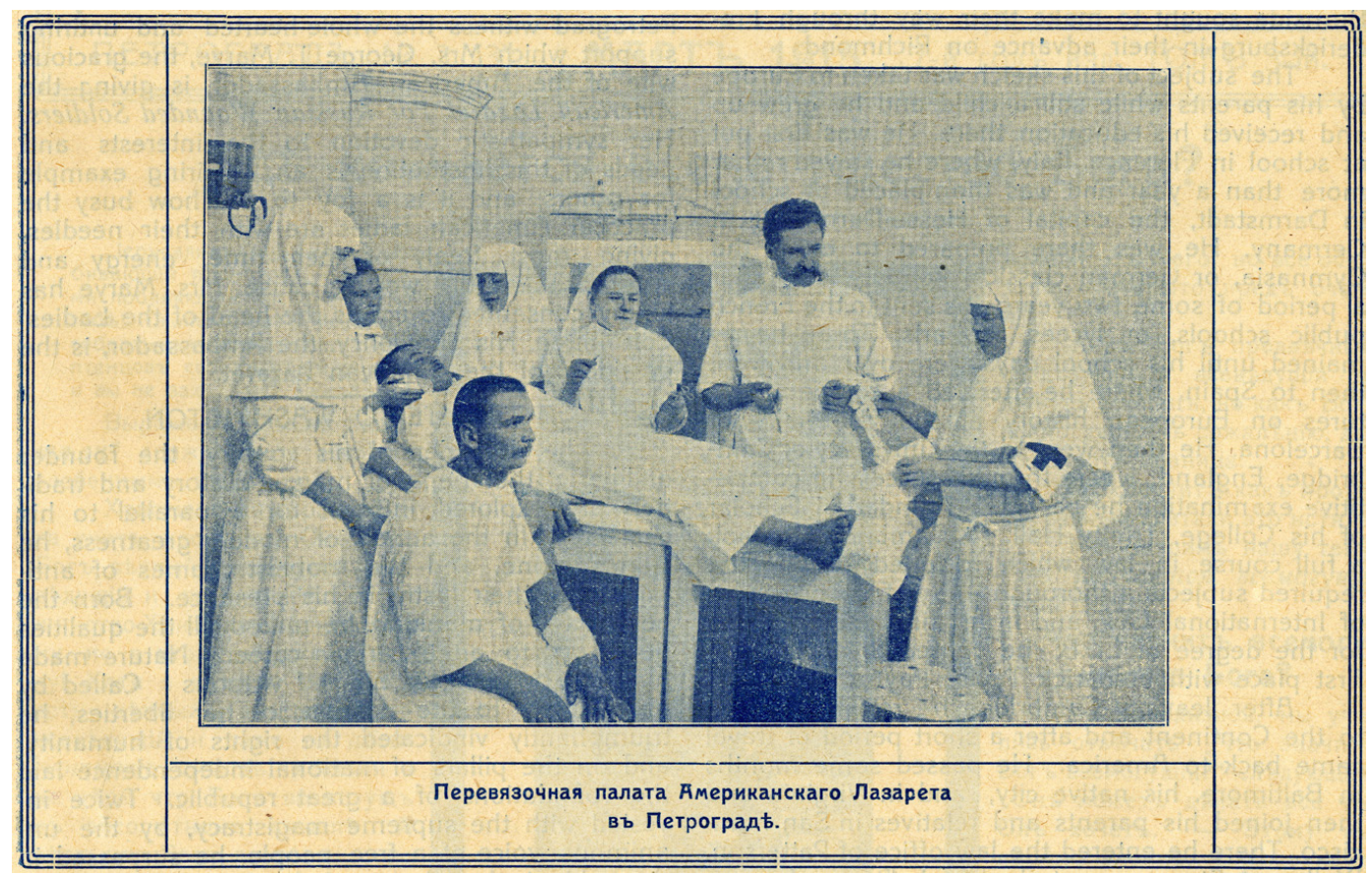

Dressing ward of the American Hospital in Petrograd. Christian Advocate, No. 74 (February 1915)

corner of the world, where he was sent as a missionary, Simons provided a brief but informative reference brochure about Russia, including a note on its geography, diversified with a variety of climate zones and population distribution, and referred to as a "cosmopolitan constituency," religions, with an emphasis on "the Mohammedan Problem," and favorable conditions for the evangelical movement. Simons noted the tsar's advances toward freedom of conscience, and described a handwritten copy of the Greek Bible Codex Sinaiticus, which he considered the most valuable treasure of the Imperial Library.

\section{Promoting mutual friendly relations between Russia and America}

When Nikolai Andreevich Borodin, a vice president of the Society for Promoting Mutual Friendly Relations between Russia and America, asked Simons to comment on initiatives that brought America and Russia closer together, especially in religious and charitable matters, Simons mentioned several publications of the Orthodox Church in the United States, such as The Russian American Messenger of the Cathedral of St. Nicholas, the semimonthly Zealot of the Christian Orthodoxy, and The Constructive Quarterly, published in New York, with well-known Russian scholars on its editorial board (Christian Advocate, no. 86, (February 1916), 32(16)). Similarly, the Christian Advocate announced other non-religious editions, initiated to increase American awareness about Russia, its social and economic life, literature, culture, and science. Simons mentions the New York-based Russian Review, edited by journalist, economist and translator Leo Pasvolsky (Christian Advocate, no. 90, (June 1916), 95(7)). Simons reported about efforts of American diplomats, statesmen, publicists, and businessmen, who became acquainted with Russia and attempted to dispel the most harmful preju- 
dices. One such effort was undertaken by Dr. Curtis Guild, a former ambassador to Russia, who shortly before his death was engaged in raising funds for the relief of the war-stricken people, delivering lectures and writing articles on Russia. When WWI broke out, the American Methodist Episcopal Church participated in disbursing funds among destitute families throughout Russia, and Simons himself issued appeals for shoes and clothing for refugees (Christian Advocate, no. 86 (February 1916): 24).

When American Ambassador David Francis came to Petrograd in 1916, Simons offered the governor his services as a guide to the city's "most important historic sites and famous arts treasures." Inspecting the scrapbooks of the Methodist Foreign Mission Board maintained by the United Methodist Archives, I came across several images that, although immediately recognizable, seemed out of place in their collections. These were photos of three famous Russian sculptures, namely 'Ivan the Terrible' by Mark Matveevich Antokol'sky (1843-1902), 'A Peasant in Distress' by Matvey Afanasievich Chizhov (1838-1916), and 'The First Step' by Fyodor Fyodorovich Kamensky (1836-1913). Puzzled, I assumed that the photos were taken by Simons, since a book with annotated comments for each photo was lost when the archive was moved from New York City, where the Board of Global Ministries was once situated, to New Jersey. The photos were considered unidentifiable, so I volunteered to provide the depository with a brief commentary about each of them. While the lives and work of Mark Antokol'sky and Matvey Chizhov are well-researched, the fate of the third artist, Fyodor Kamensky, is less well-known to either specialists or the general public. It was in the process of compiling a summary of the sculptor's biography and artistic legacy that the idea of conducting a more thorough investigation first arose, along with the awareness that the research might shed significant light upon the story of an extraordinary Russian-American. The findings surpassed all expectations, revealing the American odyssey of Fyodor Kamensky, a Russian socialist humanist, who renounced his promising future as an artist under the patronage of Alexander II and immigrated to the United States, pursuing "gradual and unpretentious selfimprovement," while dreaming of a "regenerated" and just humanity.

Among other factors that drew American attention to Russia, Simons mentioned church music. Russian liturgical music remained the pastor's most profound passion, and some of it even 'migrated' into Methodist hymnals. One such song was Коль славен (Kol slaven), by Ukranian composer Dmitrii Bortniansky, known to English-speaking worshipers as tune 134, or St. Petersburg. Simons not only loved to perform the tune during services, but modernized the lyrics, giving the hymn the new title of "The Toilers' Friend," and dedicated a new verse "to the dear Russian people."

At the turn of the twentieth century, as the author of The American Mission and the Evil Empire, David S. Foglesong wrote, "American political, commercial, and evangelical energies surged overseas," and Russia was one of many countries Americans sough to explore "to liberalize, develop and redeem" $(2007,4)$. American citizens from all strata of society, including business interests, journalists, missionaries, philanthropists, and academics flocked to the Russian capital. 
As Harper Barnes described it, the mass of Americans in Petersburg / Petrograd at the time presented a "proliferating number of official, semi-official, unofficial, and downright clandestine" visitors (Barnes, 277). The American colony in St. Petersburg had a distinctive social life. The unprecedented influx of Americans into Russia was noted on the pages of the Christian Advocate, which had evolved by that time into a bilingual newsletter, reporting on social events, and anything concerning the American colony: “...scores and hundreds of friends and tourists from America have dropped in[to] Methodist headquarters... these welcome visitors represent various professions and denominations. Among these there have been bishops, university and college presidents, secretaries of various boards, editors and journalists, men of the diplomatic and consular service, missionaries, and business people. Practically all have expressed one and the same opinion: Russia is a great and wonderful country and we shall only have kind words to speak of this land and nation" (Christian Advocate, no. 76 (April 1915), 42 (18)). Many of those official and unofficial messengers "of the open eye, ear and heart became acquainted with the country, thus removing many prejudices that might otherwise tend to do harm" (Christian Advocate, no. 86 (February 1916), 32 (16)). In 1910, Pastor Simons wrote that their Petersburg mission became a "sort of Mecca for the passing missioners of our church and other fellow sojourners, many of whom visited me this year" (Christian Advocate, no. 8 (20), (August 1910), 68).

Americans came to the House of Methodists for their national holidays celebrations, such as Thanksgiving and Christmas. ${ }^{15}$ Among other distinguished visitors, Doctor Simons welcomed former Ambassador to Russia John Wallace Riddle (1910), Ambassadors Marye and Francis, Commercial attaché H.D. Baker, and Franklin A. Gaylord, General Secretary of the Russian YMCA. Doctor Jacob Sargis passed by on his way from the American Methodist medical missionary in Persia with his wife and three sons, as well as the well-known Swarthmore College professor Dr. Benjamin F. Battin, who represented the World Alliance of Churches for Promoting International Peace. Prominent American sociologist Mary Boyle O'Reilly, a scholar of women in industry and in prison, as well as children's lives in large cities, paid a visit to the church, while delivering lectures in Russia. Dr. L.H. Murlin, the president of Boston University, whose lecture "Impressions from Petrograd" was in demand "fully up to the limit of [his] time and strength," also visited (Christian Advocate, no. 76 (April 1915), 42 (18)). In March 1915 a delegation of Red Cross doctors and 25 nurses passing through Petrograd on their way to Kiev, where Americans operated a field hospital, paid a visit to the American church in the city. Numerous American and British expatriates and other foreign sojourners gathered at the church on Thursday afternoons for a pleasant time and friendly company.

\section{Pastor's family as good will ambassadors}

The story would not be complete without mentioning Simons' companions, such as his mother, Mrs. Ottilie Simons and Miss Ottilie Aurora Simons, the pas-

${ }^{15}$ Simons described the Thanksgiving celebration that took place in the Chapel in Petrograd, in 1915 (Christian Advocate, no. 87 (March 1916), 54 (14)). 


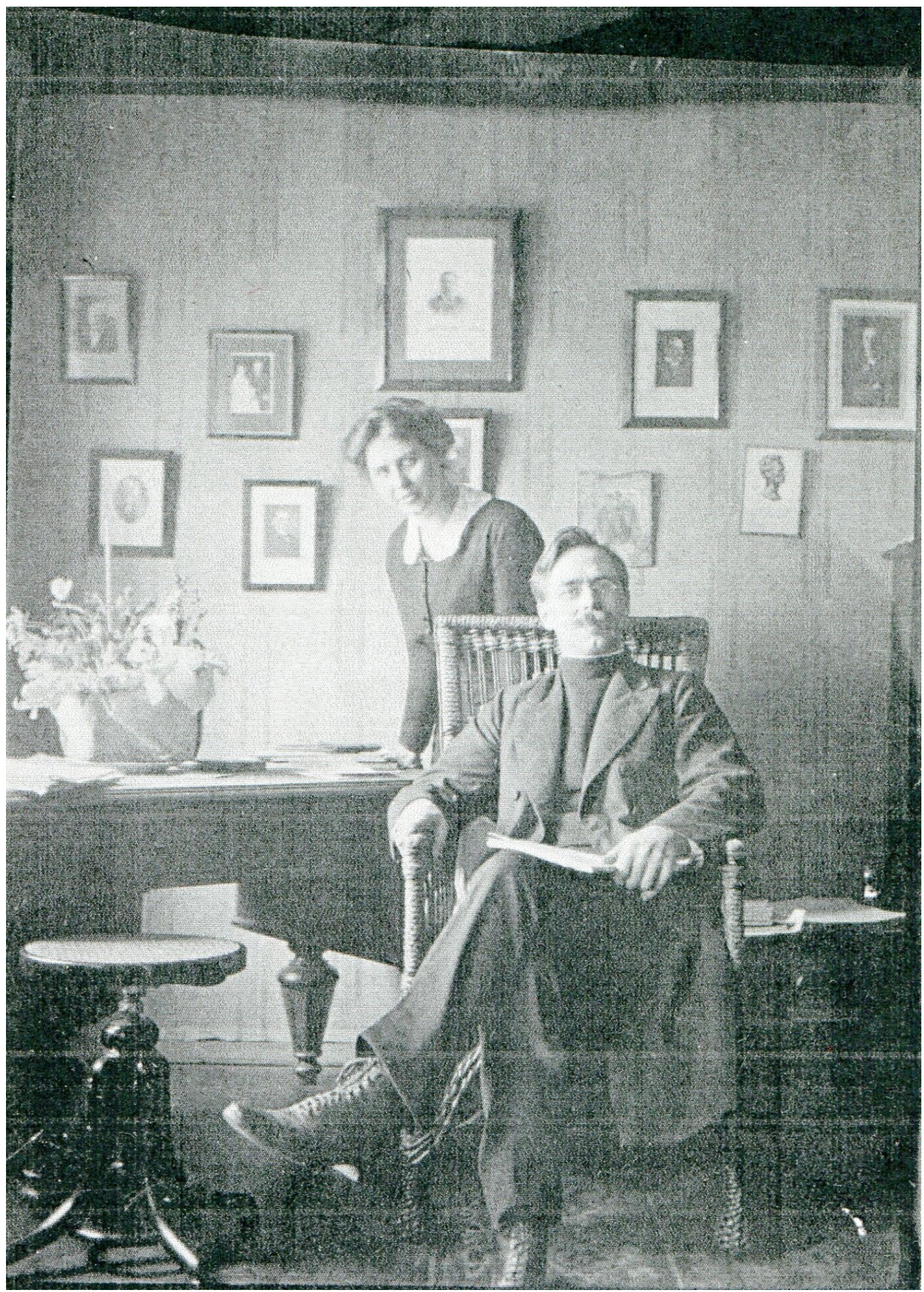

Pastor Simons and his sister Ms. Ottilie A. Simons in their apartment in Petersburg, 1911. Simons File 1185-1-3:19. Missionary Files Series, United Methodist Church Archives, Madison, New Jersey. Courtesy of the United Methodist Commission on Archives and History. 
tor's sister. Although both women were ardent participants in missionary work in St. Petersburg, its environs, and the Baltic States, there have been few references to their Russian experiences. They became actively involved in mission affairs and selflessly dedicated themselves to social work and humanitarian aid. Both mother and sister were well known to residents of Vasilievsky Island, who credited the women for their explicit faith, strong will, common sense, and good spirits. It was Simons' mother who encouraged her son to go to Russia, in spite of his hesitance. Knowing neither the language nor customs of the strange land, the pastor's mother dedicated herself wholeheartedly to serve its destitute.

Both women organized Easter and Christmas celebrations, distributed New Year's presents among neighborhood children from impoverished households, and provided short- and long-term care for the sick. The first issue of Christian Advocate, in 1911, reported about a magnificent Christmas celebration organized in the American Church, attended by more than 500 children and adults (Christian Advocate, 2 (1), (January

Mrs. Ottilie Simons (1852-1913), mother of pastor Simons. Simons File 1185-1-3:19. Missionary Files Series, United Methodist Church Archives, Madison, New Jersey. Courtesy of the United Methodist Commission on Archives and History.

1911), 4). When Mrs. Simons died in 1913, she was buried in St. Petersburg, mourned and remembered by many. She was proclaimed the mother of Methodism in Russia. A shelter in Finland was named after her in Khandrovo, where her son George Simons had preached his first sermon upon arriving in Russia (Christian Advocate, 10 (34), (October 1913), 1 (37)).

\section{Epilogue}

The American Methodist Episcopal Church remained in the capital after the embassy left Petrograd in 1918. Simons estimated that there were still "around 30 American nationals resided in the city." He appealed to his compatriots remaining in Petrograd, urging them to be "mutually helpful," and announced that the American church would gladly continue to tender its services to all Americans "irrespective of race, color, or creed" (Simons, 1918). After finally being ordered to leave the country, he passed the mission along to Sister Anna Eklund, a Finnish deaconess educated at the Methodist Institute and Hospital at Frankfort-amMain, Germany and appointed as a deaconess in Russia in 1908 (Malone, 241). Although Simons could not officially return to Russia, he remained close by in 


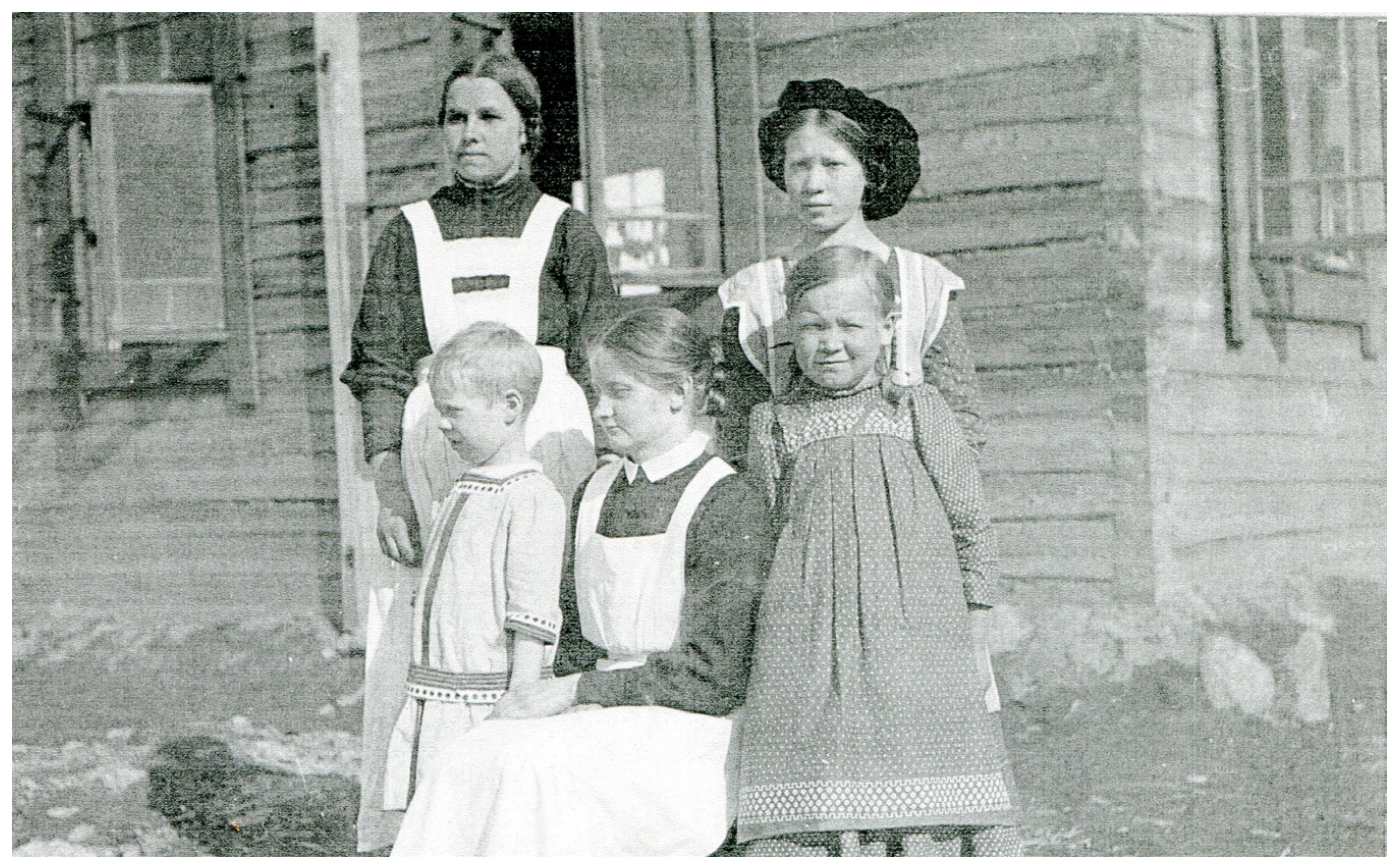

Deaconess Ida and the children at the Ottilie Simons Children's Home in Handrovo, Russia. Simons File 1185-1-3:19. Missionary Files Series, United Methodist Church Archives, Madison, New Jersey. Courtesy of the United Methodist Commission on Archives and History.

Finland, and when a massive famine struck Russia in 1921, and thousands were dying from starvation, Simons continued to be actively involved in their fate, through participation in the "American Methodist Relief and Child Welfare" operation that he helped manage from Helsinki and later from Riga. In 1924, Methodist bishop Nuelsen reported to the General Conference that George Simons was still effectively operating from Riga, and was permitted to travel to Russia, where Sister Anna Eklund continued her work in Leningrad (Malone, 259). ${ }^{16}$ In 1927, at its annual conference held in Riga, Methodists marked the twentieth anniversary of the Russian Mission, honoring Pastor Simons "for his service and looked back upon the history of the mission with pride" (Malone, 259).

If Simons' friend Marshall was right, and there is "such thing as Fate," then pastor Simons was destined not only to pioneer Methodism in Russia, but also to stand at the foundation of public diplomacy through close personal relations with Russians and direct involvement in the life of the city and region. Having settled in the capital to facilitate spiritual work and relief initiatives, Simons represented a vanguard of good-willed citizens and patriots, securing and enriching an excellent environment for constructive dialogue, and promoting "good feeling among Russians." Finding himself in the midst of a series of politically and socially-charged dramatic events, he directed his efforts toward establishing mutual understanding and trust, while promoting America, securing American interests, and meeting the spiritual needs of his compatriots, other foreigners, as well as Russian natives.

${ }^{16}$ Malone refers to 1924 John Nuelsen's "Report of the Zurich Area," published in Daily Christian Advocate, XX (May 3), 66-70. 
The appointment helped the pastor re-discover Russia and reconsider his reserved opinions about the country, which became a crucial inducement to remain an advocate for the nation and its people for years to come. In the Christian Advocate in 1916, Simons wrote that he was grateful to be given a chance to "study this great Slavic nation at first hand." After eight years of residence in Petersburg/ Petrograd, he confessed: "I, for one, believe in Russia, in her broad nature and in the valuable contribution which she is making, and most generally too, to the sum total of world culture. The world can't yet get along without Russia any more than Russia could get along without the world..." (Christian Advocate, no. 85 (January 1916), 13). Similar to many of his compatriots, in spite of hesitations, Simons was grateful for his experience in Russia, "being blessed with a great opportunity to serve the Lord [there]," where his responsibilities were so inspiring, that "[he] would never swap it for a position anywhere in [the] largest, most lucrative and influential missions in the States" (Christian Advocate, no. 8 (August 1910), 69 (171)).

The history of American Methodists in St. Petersburg spanned an era of unprecedented social and political turmoil and strife, embodying a case study in public diplomacy that produced a broad spectrum of avenues for American engagement with Russia beyond the reach of governmental institutions. It features the story of pioneering Methodism in Russia's northern capital by American pastor George Albert Simons, who was involved in missionary and charitable activities throughout the course of WWI, the revolutions, and their immediate aftermath. As Simons' Methodist church ultimately became the locus of the American colony in the city, its social and political priorities, publishing activities, and the role its members played as cultural messengers and good-will ambassadors contributed to a growing appreciation of Russia, its people, culture and history among American sojourners and their compatriots back home. Thanks to the mission's direct participation in the life of the city and close contacts with its denizens, Simons' perceptions of Russia would dramatically evolve during the course of his years there. As with many Americans who shared the experience of living and working in the country, by the end of his tenure, Simons would come to see Russia as an American venue, rather than an American problem. And even after the Bolshevik seizure of power, whenever possible, he remained immersed with the country's social, cultural, and economic affairs, in spite of bitter resentments toward the new regime.

\section{References}

Barnes, Harper. (2001). Standing on a Volcano: The Life and Times of David Rowland Francis. St. Louis: Missouri Historical Society Press and The Francis Press.

Bertash, Alexander V., Elena I. Zherikhina, and Mikhail G. Talalaĭ, (1992). Khrami Peterburga: spravochnik-putevoditel' (Temples of St. Petersburg). Sankt-Peterburg: Informatsionno-izdatel'skoe agentstvo "LIK". 
City Hospital of the American Colony. (1916). Letters from Russian Soldiers Who Have Been Cared for at the Hospital. Petrograd: American Methodist Episcopal Chapel.

Dunstan, John. (1980). “George A. Simons and the Khristianski Pobornik: A Neglected Source on St. Petersburg Methodism." Methodist History, vol. 19 (October), 21- 40.

Foglesong, David S. (1997). "Redeeming Russia? American Missionaries and Tsarist Russia, 1886 - 1917." Religion, State and Society, vol. 25 (4), 353368.

. (2007). The American Mission and the 'Evil Empire'. Cambridge: Cambridge University Press.

Kimbrough, Jr., Steven T., ed. (1995). Methodism in Russia and the Baltic States: History and Renewal. Nashville: Abingdon Press.

_. (2001). Sister Anna Eklund (1867 - 1949): A Methodist Saint in Russia. Hew Words and Witness, St. Petersburg 1908 - 1931. New York: GBGM Books.

- (2009). A Pictorial Panorama of Early Russian Methodism, 1889 - 1931. Madison, N. J.: General Commission on Archives and History, The United Methodist Church.

Lowrie, Donald A. (1918). Lowrie to Brackett, 15 May 15 1918. Donald A. Lowrie Papers, series no. 15/35/53, box. 1. Russian and East European Center. Liberal Arts and Sciences. The University of Illinois Archives, Champaign - Urbana.

Malone, Donald Carl. (1980). "A Methodist Venture in Bolshevik Russia." Methodist History, vol. 18 (July), 239 - 261.

Marshall, Leslie A. (1928). The Romance of a Tract and Its Sequel: The Story of an American Pioneer in Russia and the Baltic States. Riga: The Jubilee Fund Commission of the Baltic and Slavic Mission Conference of the Methodist Episcopal Church. Latvian Farmers' Union Printing Office.

Miller, Matthew Lee. (2012). The American YMCA and Russian Culture: The Preservation and Expansion of Orthodox Christianity, 1900-1940. Lexington Books.

Perovsky Petrovo Solovovo, Mikhail Mikhailovich. (1920). Perovsky to Hapgood. Paris, October 1920 and Perovsky to Hapgood, Christiania, Norway, 1920. Isabel Florence Hapgood Papers. (1864-1922). Manuscript \& Archives Division (MAD), folder 1, box 3, New York Public Library (NYPL).

(1916). "Russian Soldiers Are Grateful to Americans." New York Times, June 25, SM12.

Simons, George A. (1913). And the Rest of Europe: the Response for Russia in the Call of Nations. Zurich: World's Seventh Sunday School Convention.

_. (1918). Greetings to American Nationals in Petrograd, 22 March 1918. David R. Francis Papers, The Missouri Historical Society.

Simons File 1185-1-3:19. Missionary Files Series, United Methodist Church Archives, Madison, New Jersey. 
Teryukova, Ekaterina Aleksandrovna. (2004). "Iz istorii protestantizma v Rossii. (A Propos the History of Protestantism in Russia)." Vestnik SanktPetersburgskogo universiteta, 6 (4): 53-60.

_. (2005). "Angloiazychniye protestantskie obschiny" (English Speaking Protestant Communities). In Tri veka Sankt-Peterburga: entsiklopediia $v$ trekh tomakh, edited by Pyotr Evgenyevich Bukharkin., tom 2, kn. 1. SanktPeterburg: Filologicheskǐ fakul'tet Sankt - Peterburgskogo gosudarstvennogo universiteta, $140-146$.

- (2009). Angloiazychnye protestantskie obshchiny Peterburga nachala XX veka: verouchenie i sotsial'naia de Tatel'nost' (English speaking Protestant communities of Petersburg in the beginning of the 20th cent.: religious doctrine and social activity). Sankt-Peterburg: IPTS SPGUTD.

United States. Congress. Committee on Judiciary, 1919. Bolshevik Propaganda. Hearings before a Subcommittee of the Committee on the Judiciary United States Senate, Sixty-fifth Congress, Third Session and Thereafter, Pursuant to S. Res.439 and 469. February 11, 1919, to March 10, 1919. Washington. A collection of Christian Advocate for 1909-1917. 